\title{
AN ERROR ANALYSIS OF ENGLISH SIMPLE PRESENT TENSE OF THE SECOND YEAR STUDENTS OF SMP $N 1$ SUSUKAN REGENCY OF SEMARANG IN THE ACADEMIC YEAR 2003/2004
}

\author{
Agus Safudin \\ English Department of Educational Faculty \\ State Institute for Islamic Studies (STAIN) Salatiga \\ JI. Tentara Pelajar No. 2 Salatiga, Central Java, Indonesia \\ Aguss5@gmail.com
}

\begin{abstract}
The aim of this research is to find out how far the errors of simple present tense produced by the second year students of SMP N 1 Susukan. The research was conducted at State Junior High School (SMP N) 1 Susukan, Regency of Semarang, Central Java, Indonesia. The objects of this research were the eighth graders. This is quantitative research. The writer uses random sampling by lottery. There are about 75 students and the writer took $50 \%$ as the sample. The errors made by the students were divided into eight aspects. (1) Error in using auxiliary is $36.75 \%$. (2) Error in using plural noun is $22.90 \%$. (3) Error in using to be is (am, is, are,) is 7.69\%. (4) Error in adverb of manner is $4.27 \%$. (5) Error in using verb in simple present tense is $4.78 \%$. (6) Error in using possessive sentence 5.24\%. (7) Error in using imperative sentence is $0.34 \%$. (8) Error due to ignorant is $11.28 \%$. Relating to those errors there should be the preventing efforts by the teachers such as providing lots of examples of English and Indonesian sentences so that the students have greater understanding about the difference of those languages.
\end{abstract}

Keywords: Error Analysis, Simple Present Tense, SMP N 1 Susukan

\section{Abstrak}

Tujuan dari penelitian ini adalah untuk mengetahui sejauh mana kesalahan yang dilakukan oleh siswa tahun kedua, SMP N 1 Susukan, dalam membuat kalimat simple present tense. Penelitian ini dilakukan di SMP Negeri ( SMP N ) 1 Susukan, Kabupaten Semarang, Jawa Tengah, Indonesia. Obyek penelitian adalah siswa kelas delapan. Dalam penelitian kuantitatif ini, penulis menggunakan random sampling. dari 75 siswa yang ada, peneliti mengambil $50 \%$ dari populasi tersebut sebagai sampel. Kesalahan yang dibuat oleh siswa dikelompokkan menjadi delapan aspek. ( 1 ) Kesalahan dalam menggunakan auxiliary $(36,75 \%)$, ( 2 ) Kesalahan dalam 
menggunakan kata benda jamak sebanyak $22.90 \%$, ( 3 ) Kesalahan dalam menggunakan to be( am, is, are ) sebanyak $7.69 \%$, ( 4 ) Kesalahan dalam menggunakan keterangan cara $(4,27 \%),(5)$ Kesalahan saat menggunakan kata kerja dalam simple present tense $(4.78 \%$ ) . ( 6 ) Kesalahan dalam menggunakan kalimat posesif $(5,24 \%)$, dan ( 7 ) Kesalahan dalam menggunakan kalimat imperatif sebanyak 0,34\% serta ( 8 ) Kesalahan karena kurang memperhatikan sebanyak 11,28 \%. Berkaitan dengan kesalahankesalahan tersebut, perlu adanya upaya pencegahan oleh guru seperti memberikan banyak contoh kalimat bahasa Inggris dan bahasa Indonesia sehingga siswa memiliki pemahaman yang lebih baik tentang perbedaan dalam kedua bahasa tersebut .

Kata Kunci : Analisis Kesalahan, Simple Present Tense, SMP N 1 Susukan

\section{Introduction}

Among of many languages being used in the world, English is the widest used by the people and in the books. Why English is still used and dominates the world book developments, because many authors and scientists come from English language background. It can be seen, when we are going to read, we will find many references use the English.

As the most important language, English is learned in every nation, included Indonesia, Malaysia, Thailand and the other southeast nations. Particularly for Indonesia English is regarded as the most important foreign language beside Arabic or Chinese language. This reality can be seen in many schools or universities in which, they choose it as a main subject.

As a foreign language, English is difficult to be learned by the nonnative speakers, especially in Indonesia, since there are many differences between English and Indonesia. In consequences to study language of English needed serious and full of attention.

Generally, the Indonesian students have not cover the English language yet, both active and passive, although it is taught from primary 
school, junior high school and senior high school. At primary school the material covers reading, listening, speaking, and writing (Departemen Pendidikan dan Kebudayaan, 1999: 1). The four materials are difficult enough for junior high school students so the writer wants to investigate these difficulties to be researched.

One of the junior high schools which studies English is SMP N 1 Susukan, Regency of Semarang. The students of SMP N 1 Susukan Regency of Semarang are obligated to follow the English language subject, because it's included to be the main of three subjects in the final test (ujian akhir).

Based on the problems above, the objectives of research can be specified as follows: 1.) To know the second year students of SMP N 1 Susukan, Regency of Semarang's error in learning English present tense. 2.) To know the abstracting factors of the second years students in the learning of English simple present tense. 3.) To know the teachers' efforts which have been done to overcome the errors.

\section{Sentence}

A sentence is a group of words expressing a complete thought (Warriner, and Sheilla, 1973: 15). Based on this statement we know that expressing which is conveyed is in complete thought. The complete thought means the thought is meaningful although the sentence is short.

\section{Simple Present Tense}

The simple present tense is divided into two parts namely; simple present tense with verb, (do and does) and simple present tense with (be)

a. Simple Present Tense with "Do" or "Does" 
"Do" and "Does" are same in function. They are as the auxiliaries in simple present tense.

b. Simple Present Tense with "Be"

It happens when the subject is followed by noun

\section{The uses of simple present tense}

Simple present tense is used to express

a. General truth

Example: The word needs metal. The sun rises in the east.

b. The custom and habitual actions. It is often followed by frequently, usually, everyday, and so on.

Example: I get up at 5.00 in the morning. She loves her husband.

c. To express the order or asking (for the people only)

Example: Please let me know how you get along. Get out of the room!

d. To express the future time, with the future time adverbial (Sajekti dkk, 1984: 5).

Example: she leaves next week. Classes begin the day after tomorrow.

\section{Mistakes, lapses, and error, analysis}

The interlangua is the result of the learning to corner the second language. The main characteristic of interlanguage is the divergence of structure, as we call errors in language. The errors happened systematically and happened to everyone who learns to cover the second language.

The errors being done by the people learn the new language have to be looked as the children's mistakes who learn mother language. A child who can't say / r / republic or / q / in Qor'an, will we blame them? Of course we will not blame them it was general they will say "lepublic" or "Koran". 
Corder has divided to be third of what is called as the language wrong (Prawono, 1996: 51).

Mistakes

Mistake is the divergence of the structure because the speaker is unable to convey the appropriate expression with the situation or condition.

Lapses

Lapses is the divergence of structure because the movement of concentration at the moment such as the tired, thus the lapses happens unconsciously.

Error analysis

Error is the divergence of structure because the speaker has not cover the grammar completely. The interfencer's factor of error is the language's factor which follows the certain pattern, such as Indonesian sentence has " $D$ M" (Diterangkan Menerangkan) but in English is "M D" (Menerangkan Diterangkan).

Example: Guru Bahasa Inggris (Indonesian)

The English teacher (English)

\section{Research Methodology}

\section{Population}

Suharsini Arikunto says that the population is all members of research subjects (Arikunto, 1989: 192). Population is all individuals from whom the data are collected. In this research, population is the second year students of SMP Negeri Susukan, Regency of Semarang, in academic year of 2003. 


\section{Sample}

A sample is part of population which is researched by researcher. In this research, the writer takes one class as the sample of the second year students of SMP Negeri 1 Susukan, Semarang.

\section{Sampling}

Sampling is the way of taking sample for getting the sample of research. The writer uses random sampling by lottery. In this case, the writer takes $50 \%$ from the whole population as the sample used.

\section{The method of collecting data}

Interview is done by the writer to find many real data based to the students ability in mastering tenses, while test instrument in this research is used to know the students' errors.

\section{Data Analysis}

This is the calculation of data collected. The data collected are to find out the proportion of error in each subject and to find out the proportion of error frequency in each type as well as the dominant errors occur.

\section{Discussion}

\section{The errors made by the students in learning English Simple Present Tense}

It's made by the second students of SMP N 1 Susukan in academic year 2003/2004. Here the writer did two ways to analyze the errors. The first, to find the dominant errors, is using a percentage descriptive analysis formula as follows:

$\mathrm{X}: \frac{\sum \mathrm{X}}{\sum \mathrm{X}} x 100 \%$

Where:X: Percentage of errors 
E: Various kinds of errors

T: Test item

$\sum$ : The sum of

The next is using the reselected category approach.

Table I.

Some of Errors Made by the students of SMP Negeri 1 Susukan in Academic Year 2003/2004

\begin{tabular}{|c|c|c|c|}
\hline $\begin{array}{c}\text { Number of } \\
\text { Errors }\end{array}$ & $\mathbf{E}$ & $\mathbf{T}$ & $\begin{array}{c}\text { Percentage of } \\
\text { Error }\end{array}$ \\
\hline 1 & 2 & 3 & 4 \\
\hline 1 & 7 & 40 & $17.5 \%$ \\
\hline 2 & 17 & 40 & $42.4 \%$ \\
\hline 3 & 33 & 40 & $82.45 \%$ \\
\hline 4 & 30 & 40 & $75 \%$ \\
\hline 5 & 33 & 40 & $82.5 \%$ \\
\hline 6 & 19 & 40 & $47.5 \%$ \\
\hline 7 & 1 & 40 & $3.5 \%$ \\
\hline 8 & 25 & 40 & $62.5 \%$ \\
\hline 9 & 33 & 40 & $82.5 \%$ \\
\hline 10 & 29 & 40 & $72.5 \%$ \\
\hline 11 & 26 & 40 & $65.00 \%$ \\
\hline 12 & 26 & 40 & $65.0 \%$ \\
\hline 13 & 25 & 40 & $62.5 \%$ \\
\hline 14 & 31 & 40 & $77.5 \%$ \\
\hline 15 & 33 & 40 & $82.5 \%$ \\
\hline 16 & 31 & 40 & $77.5 \%$ \\
\hline 17 & 27 & 40 & $67.5 \%$ \\
\hline 18 & 25 & 40 & $62.5 \%$ \\
\hline 19 & 28 & 40 & $7.0 \%$ \\
\hline 20 & 1 & 40 & $2.5 \%$ \\
\hline 21 & 0 & 40 & $0 \%$ \\
\hline
\end{tabular}




\begin{tabular}{|c|c|c|c|}
\hline 22 & 4 & 40 & $10 \%$ \\
\hline 23 & 4 & 40 & $10 \%$ \\
\hline 24 & 3 & 40 & $7.5 \%$ \\
\hline 25 & 5 & 40 & $12.5 \%$ \\
\hline 26 & 6 & 40 & $15 \%$ \\
\hline 27 & 0 & 40 & $0 \%$ \\
\hline 28 & 1 & 40 & $2.50 \%$ \\
\hline 29 & 0 & 40 & $0 \%$ \\
\hline 30 & 4 & 40 & $10 \%$ \\
\hline 31 & 6 & 40 & $15 \%$ \\
\hline 32 & 2 & 40 & $5 \%$ \\
\hline 33 & 5 & 40 & $12.5 \%$ \\
\hline 34 & 5 & 40 & $12.5 \%$ \\
\hline 35 & 3 & 40 & $7.5 \%$ \\
\hline 36 & 7 & 40 & $17.5 \%$ \\
\hline 37 & 2 & 40 & $5 \%$ \\
\hline 38 & 2 & 40 & $5 \%$ \\
\hline 39 & 7 & 40 & $17.5 \%$ \\
\hline 40 & 0 & 40 & $0 \%$ \\
\hline Total & 545 & 1600 & $1365 \%$ \\
\hline
\end{tabular}

Related to the simple present tense there were eight errors to be analyzed.

They were:

1. The errors in using auxiliary/modifier

2. The errors in using plural or single sentence

3. The errors in using to be

4. The errors in using adverb

5. The errors in using verb

6. The errors in using possessive sentence

7. The errors in using imperative word

8. The errors due to the ignorant 
After the writer had he computation on the proportion of occurrence partially he then computed the proportion of frequency of occurrence of errors as whole, he had the following formula:

$\mathrm{PI}=\frac{F I}{N} \chi 100 \%$

Where:

$\mathrm{PI}=$ the proportion of frequency of occurrence of errors as whole

FI: Absolute frequency of types of errors all levels

$\mathrm{N}$ : The total number of positive errors of all levels

After he had applied the formula he got the computation like below:

$\mathrm{PI}=\frac{F I}{N} \times 100 \%$

$\mathrm{PI}=\frac{612}{1600} \times 100 \%=38.25 \%$

Table II

The proportion of Frequency of Occurrence of Errors

\begin{tabular}{|c|c|c|c|c|c|}
\hline Number of & $\sum$ & $\sum \mathrm{n}$ & \multicolumn{2}{|c|}{ Errors } & \multirow{2}{*}{ (PI-Pi) \% } \\
\cline { 4 - 5 } Subject & item & & $\mathrm{Fi}$ & $\mathrm{Pi} \%$ & \\
\hline 1 & 2 & 3 & 4 & 5 & 6 \\
\hline 1 & 8 & 320 & 215 & $67.18 \%$ & $-28.93 \%$ \\
\hline 2 & 5 & 200 & 134 & $67.00 \%$ & $-28.75 \%$ \\
\hline 3 & 2 & 80 & 45 & $56.25 \%$ & $-18.00 \%$ \\
\hline 4 & 1 & 40 & 25 & $62.50 \%$ & $-24.35 \%$ \\
\hline 5 & 1 & 40 & 28 & $70.00 \%$ & $-31.75 \%$ \\
\hline 6 & 1 & 40 & 31 & $77.50 \%$ & $-39.25 \%$ \\
\hline 7 & 2 & 80 & 2 & $2.50 \%$ & $35.75 \%$ \\
\hline 8 & 20 & 800 & 66 & $8.25 \%$ & $30.00 \%$ \\
\hline Total & 40 & 1600 & 545 & $411.8 \%$ & $135.93 \%$ \\
\hline
\end{tabular}

From the table above, in descending order, the most dominant error through the least dominant one occurred in: 
1. The errors in using auxiliary/ modifier

2. The errors in using plural or single sentence

3. The errors due to the ignorant

4. The errors in using to be

5. The errors in using possessive sentence

6. The errors in using verb

7. The errors in using adverb of manner

8. The errors in using imperative sentence

\section{The Possible Causes of the Errors}

Table III.

Causes or Sources of Errors

\begin{tabular}{|c|l|c|c|}
\hline No & Causes or Sources & Total & Percentage \\
\hline 1 & Transfer & 215 & $39.45 \%$ \\
\hline 2 & Under Differentiation & 47 & $8.62 \%$ \\
\hline 3 & Split rule & 121 & $22.20 \%$ \\
\hline 4 & $\begin{array}{l}\text { Ignorance of } \\
\text { restriction }\end{array}$ & $\begin{array}{l}\text { False Concept } \\
\text { hypothesized }\end{array}$ & $24.59 \%$ \\
\hline \multicolumn{2}{|l|}{ Total } & 545 & $100 \%$ \\
\hline
\end{tabular}

Based on the table above, the writer concludes that 290 errors $(53.21 \%)$ were interlingual error. Those errors were divided in to three kinds, first caused by transfer $(215)=39.45 \%)$. Second the errors were caused by under differentiation $=(47=8.62 \%)$ and Split $(28$ errors $=4.14 \%)$.

\section{The possible ways out of preventing those Errors}

The writer believes that the obstacles of learning are natural things. The obstructing factors should get attention in order that the activity in 
learning English simple present tense has no errors. Now we come to the discussion about the possible ways out of the errors:

1. The teacher has to explain the material before giving any test. He can emphasize which is the important material in the lessons.

2. The teacher explains that there are many English's language pattern that can not be found in Indonesia language pattern.

3. The teacher gives many example of each part in teaching English tense so the students will be clear with every material had been given.

4. The teacher gives many exercise to the students in order to make the students be spirited. If they are able to apply the theory which they get in teaching-learning process, it means that the teaching-learning is to be succesful.

5. After the teacher explains all of material and the students hear it the teacher gives the opportunity, in also the students ask about the difficulties of materials.

\section{Conclusion}

1. The errors made by the students of the second year Students of SMP N 1 Susukan Regency of Semarang are 8 types. They are:

a. The errors in using auxuliary: $215=36.75 \%$

b. The errors in using plural or single sentence in simple present tense: $134=22.90 \%$

c. The errors in using to be (am, is, are) in simple present tense: $45=$ $7.69 \%$

d. The errors in using the adverb of manner in simple present tense: $25=4.27 \%$ 
e. The errors in using verb in simple present tense: $28=4.78 \%$

f. The errors in using possesive sentence: $31=5.24 \%$

g. The errors in using imperative sentence in simple present tense: 2 $=0.34 \%$

h. The errors due to the ignorant: $66=11.28 \%$

2. The possible causes of errors in using Simple Present Tense at the second year students of SMP N 1Susukan Regency of Semarang are:
a. $\quad$ Transfer $(215)$ errors $=39.45 \%$ )
b. Under differentiation $(47$ errors $=8.62 \%)$
c. Split $(28$ errors $=5.14 \%)$
d. Ignorance of rule restriction $(121$ errors $=22.20 \%)$
e. False concept hypothesized (134 errors 24.29\%)

3. The posissible ways out preventing those errors, in using Simple Present Tense at the second year students of SMP N 1Susukan Regency of Semarang

a. The teacher should ecplain the materials firstly and emphasize the differences between Indonesian pattern and English language, both in the grammar or structure

b. The teacher provides a lot of example of sentences using simple present tense and ask students to compare English and Indonesian sentences so that they find the differencees between them.

c. The teacher gives opportunity to the students and ask the possible difficulties dealing with the materials.

\section{References}

Departemen Pendidikan dan Kebudayaan. 1999. Garis Garis Besar Pengajaran. Jakarta: Aksara Jakarta Press. 
Suharsimi, Arikunto. 1989. Metodologi research untuk penulisan paper, skripsi, Thesis dan Disertasi. Yogyakarta: Andi Ofset.

John Warriner, Aws Sheilla. 1973. English Grammar and Composition. New York.

Sajekti, et al. 1984. Buku Materi Pokok Bahasa Inggris I Modul Universitas Terbuka. Jakarta: Ratna Sayekti Jakarta.

Pranowo. 1996. Analisis Pengajaran Bahasa. Yogyakarta: Gadjah Mada University Press. 